〔89】ポリカーボネートのガラス状態と延伸性

\author{
畠山立子* ・金綱久明*
}

(1970 年 3 月 11 日受理)

\begin{abstract}
要 旨 ガラス転移温度 $\left(T_{g}\right)$ が高く, 室温で安定な無定形物が得られるモデルポリマーとして, ポリカーボネートを選び、ガラス状態の变化と延伸性などとの関係を得ることを目的とした。ポりカ 一ボネートを溶融状態から急冷すると，X線的には完全な無定形物が得られ，これを差動熱量計 (DSC) 飞よって测定すると, $130^{\circ} \mathrm{C} に T_{g}$ が観測され，その他の cold crystallization や融解ビー クは見出されない。この未処理試料を $100 \sim 150^{\circ} \mathrm{C}$ で種々の時間熱処理することによって，Toに括 ける吸熱ビークの高さが異なる試料が得られる。ピークの高さと密度の間にはほぼ比例関係がなりた ち，ピークの高さが高くなるにつれて，非晶鎖の充てんが密になることがかかった。熱処理試料を延 伸すると，熱処理温度をともに初期降伏応力 $G_{1}$ は增大し，破断強度 $G_{2}$, 破断伸度 $L_{2}$ は隇少する。 これら $G_{1}$ などの值とサーモグラム上のピーク高さの間には，拉よその比例関係がなりたつ。Gの增 大は熱処理による非晶鎖の充てんにより二次結合が增大したためであり，また $G_{2}, L_{2}$ の減少はぜい 性が增加してすべりが起こらなくなったためと考えられる。
\end{abstract}

\section{1. 緒言}

非晶牲ポリマーを溶融状態よりガラス転移領域で非常 にゆっくり冷却するか，またはガラス転移温度 $\left(T_{g}\right)$ で 長時間熱処理すると, サーモクラムにはガラス転移温度 に吸熱ピークが高くなって現われることが知られてい

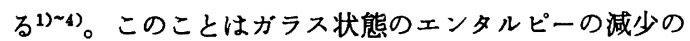
ためと解积される2)、4)。われわれは今までに熱処理など によって異なったガラス状態をもつ非晶性ポリマーをつ くり，ガラス転移挙動の变化について追求してきた。し かし，ガラス状態の違いと物性の変化については，まだ ほとんと報告されていないら。

この論文ではこれらの関係についての知見を得るた めに，実験しやすいモデルポリマーとして，ガラス転移 温度が高く, $T_{0}$ より低い温度で処理しても，もちろん 結晶化が起こりにくいポリカーボネートを選び, 非晶領 域の構造の違いが延伸性にどのような影響を与えるかに ついて追求した。

\section{2. 実験}

\section{1. 試料の調製}

三菱江戸川化学(株)製ポリカーボネートチップ, ニー ピロンE 2000 を真空乾燥したのち， $240 \sim 250^{\circ} \mathrm{C}$ におい て $150 \mathrm{~kg} / \mathrm{cm}^{2}$ でプレスしたのち, フェロ板にはさんた ままドライアイスェタノール中へ急冷した。室温へ戻 して真空乾燥したのち測定に供した。熱処理は，このフ ィルムを空気中で所定温度, 時間で行なったのち室温へ 急冷した。

\footnotetext{
* 織維高分子材料研究所（横浜市神奈川区沢渡 4)
}

\section{2. 測定方法}

2.2.1. 熱 解 析

パーキンエルマー社製差動熱量計 DSC-IB 型を用い, $\mathrm{N}_{2}$ 気流中 $16^{\circ} \mathrm{C} / \mathrm{min}$ で昇温した。試料の重量は約 10 $\mathrm{mg}$ である。

\subsection{2. 強伸度試験}

東洋測機テンシロン UTM-III 型を用い， 1 分間 $4 \%$ 引張速度で延伸した。測定は $20^{\circ} \mathrm{C} て ゙$ 行なった。

\subsection{3. $X$ 線回折}

理学電機株式会社製 X 線回折装置により, 写真法拈よ びガイガーカウンターにより測定した。

\subsection{4. 密度}

ピクノメーターにより浮沈法で瞃酸カリウム水溶夜を 用い $25^{\circ} \mathrm{C}$ で測定した。

\section{3. 結果と考察}

\section{1. 熱的性質}

ポリカーボネートを2.1.で述べたような方法に従っ て作製すると，Fig. 1 に示すよらな完全な無定形物と してX線写真に観測される。また DSC より得られたサ 一モグラムには $130^{\circ} \mathrm{C}$ 付近に吸熱側へのペースライン の片寄りが認められ, cold crystallization による発熱ピ 一クや融解による吸熱ピークは特に認められなかった。 ポリカーボネートのサーモグラムはすでに O'Relly ら7 によって得られてはいるが, 詳細な解析, 特に $T_{g}$ 付近 のそれについては行なわれていない。130〜 $160^{\circ} \mathrm{C}$ に認 められる四熱変化は $T_{0}$ によるものであり, 粘弾牲測定 による $\alpha$ 分散と対応している ${ }^{8) \sim 10) 。 ~}$

このような無定形なポリカーボネートを100 $1500^{\circ} \mathrm{C}$ 


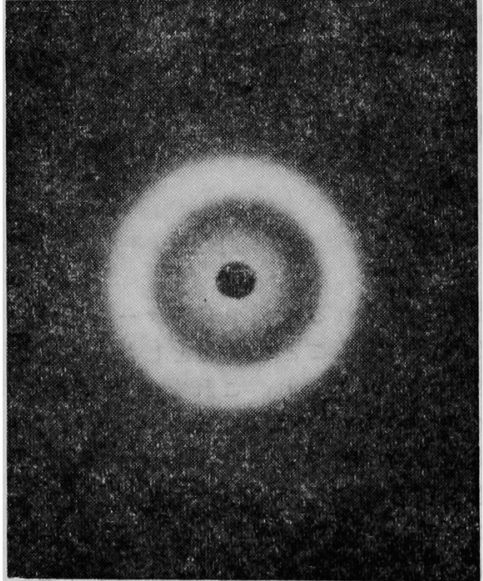

Fig. 1. X-ray diffraction photograph of polycarbonate quenched from the melt to $-78^{\circ} \mathrm{C}$.

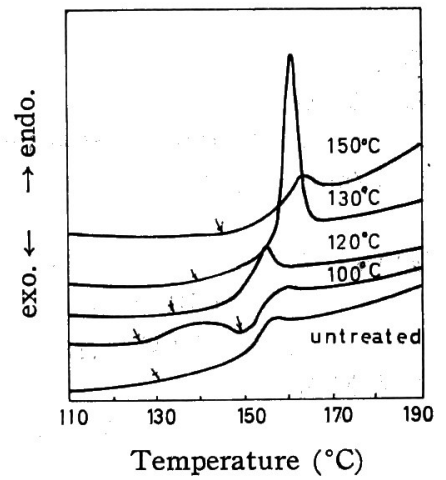

Scanning rate $16^{\circ} \mathrm{C} / \mathrm{min}$

Temperatures of treatment are shown in Figure.

Time of treatment $16 \mathrm{hr}$

Fig. 2. Thermograms of polycarbonate treated at various temperatures.

で 16 時間熱処理したとさのサーモグラムをFig. 2 に示 した。典型的な非晶牲ポリマーと同様の挙動を示してい る。ポリスチレンタ),11), ポリ塩化ビニル83,12) に拈いて 見出されたと同じょうに, $T_{q}$ より低い $100^{\circ} \mathrm{C} 16$ 時間処 理で $T_{g}$ Kつのクニック $\left(T_{g l}, T_{g h}\right)$ が観察され，ポリ カーボネートに括いても非晶領域の分割が起こることを 示している。この試料の粘弾牲測定を行ならと, $\tan \delta-$ 温度曲線に主分散より低い約 $100^{\circ} \mathrm{C}$ 付近にショルダー 状の $\beta$ 分散が見出される。試料の熱履歴はことなるが， 冨川ら ${ }^{8)}$ は $\beta$ 分散が $60 \sim 120^{\circ} \mathrm{C}$ の間にあり, 処理条件 の違いによって変化することを見出している。冨川ら は, $\beta$ 分散は分子間結合力の不均性が解消するための運
動によるとし，熱処理によって消失するとしている。試 料作製の基準がわれわれの場合と一致しないか，サーモ グラム上に現われる $T_{a l}$ と分散 $\beta$ とは対応関係にあるむ のと考光られる。

Fig. 2 によると, $T_{g h}$ のピークの高さは， $T_{g}$ に护け る熱処理によって最も高くなることがわかる。 $T_{g}$ ，ピー ク温度, ピークの高さと熱処理温度の関係を Fig. 3 K 示した。熱処理温度が高くなると， $T_{a}$ およびピーク温 度もやや高温側へ移行し，ピークの高さも $130 \sim 140^{\circ} \mathrm{C}$ で最高值をとることがわかる。

熱処理した試料の密度を測定し処理温度に対してプロ ットすると, Fig. 4 が得られる。处理温度が $T_{g}$ に近つ くにつれて, 密度 $(\rho)$ が大きくなっている。この結果は

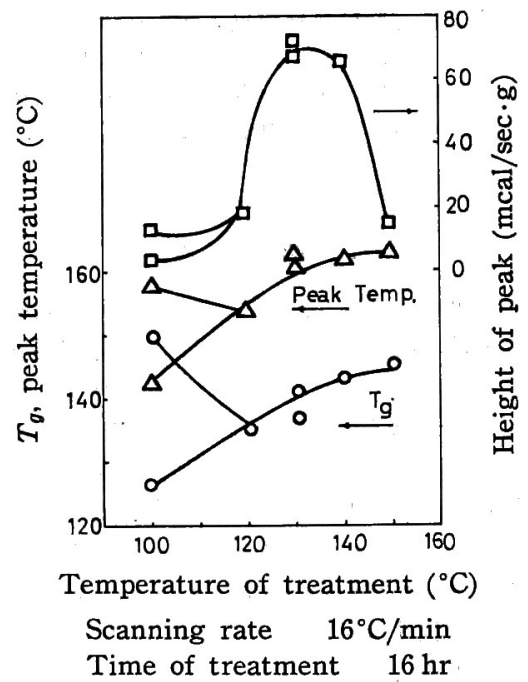

Fig. 3. Change in $T_{g}$, temperature and height of transition peak with temperature of treatment.

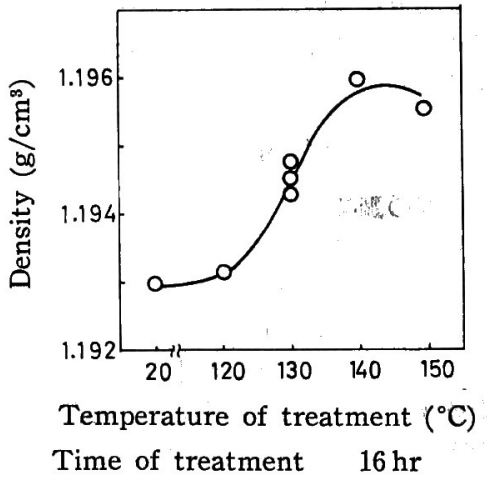

Fig. 4. Change in density with temperature of treatment. 


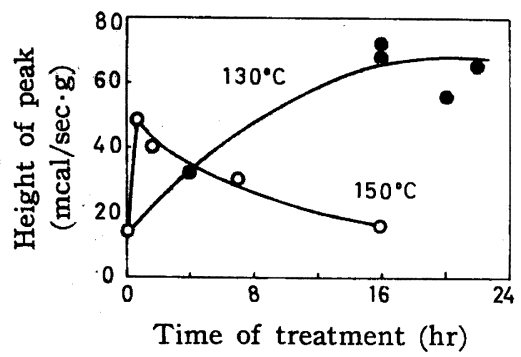

Scanningrate $16^{\circ} \mathrm{C} / \mathrm{min}$

The temperature of treatment are shown in Figure.

Fig. 5. Change in height of transition peak with time of treatment for polycarbonate treated at $130^{\circ} \mathrm{C}$ and $150^{\circ} \mathrm{C}$.

藤本ら9)の結果とも照応している。

Fig. 5 に $130^{\circ} \mathrm{C}$ および $150^{\circ} \mathrm{C} て ゙$ 熱処理したときのピ ークの高さの処理時間依存性を示した。130ㄷ C゙処理し た場合はポリスチレンの場合と同じように ${ }^{3)}$ ，処理時間

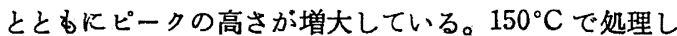
た場合は数十分で最大值をとる。Fig. 2 でもみられると

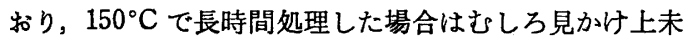
処理試料と同じような挙動を示している。Fig. 2〜4の 試料は X 線回折図からは $2 \theta=17.5^{\circ}$ にハローリングを すつ無定形で未処理試料と全く変りない。しかし 140〜 $150^{\circ} \mathrm{C}$ で長時間, たとえば 16 時間処理したときは，サ 一モグラム上に非常に小さな， $T_{g}$ のピークより小さい 融解ピークが得られるので， $\mathrm{X}$ 線的には検知されない微 結晶が発生しているものと考えられる。これらの微結 晶の束縛によって，非晶領域の再配置が妨げられること が，長時間処理におけるピーク減少の要因になっている ものと考えられる。

Fig. 3 および 4 に示した試料の密度 $\rho$ とピーク高さ

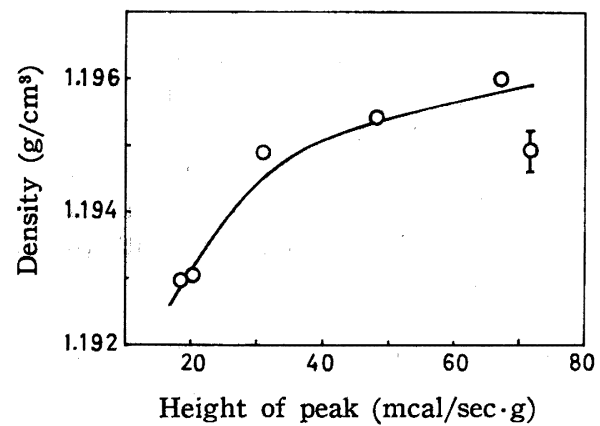

Fig. 6. Relationship between density at $25^{\circ} \mathrm{C}$ and height of transition peak for amorphous polycarbonate treated at various temperatures.
の関係を Fig. 6 に示した。ピークの高さと密度とは特 扣よその比例関係があることがわかる。このことは，ガ ラス状態のエンタルピーの減少は， $\rho$ の増大として観測 される非晶鎖の充てんによる再配置が，その主たる要因 であることを示している。

\section{2. 延伸性の変化}

結晶性高分子の無定形物のガラス状態の変化と機械的 性質の関連牲については, 三石らら) がポリエチレンテレ フタレートを紡系後室温に放置する時間を変えて, 強伸 度を測定した結果がある。室温に放置する時間が長くな るにつれて, ネッキング応力の増大が認められるが, 放 置時間との定量的な関連については示していない。

3.1. ですでに述べたように，ポリカーボネートの $T_{g}$ は高温にあるため， $T_{\sigma}$ より低い温度で処理することに より, 各種の異なったガラス状態をるち室温で比較的安 定な試料を容易に得ることができる。これらの試料の強 伸度曲線から得られた結果を, サーモグラムから得られ た結果と比較することにより，ガラス状態の变化と物牲 変化の関連をとらえることがでさる。

溶融状態から急冷したポリカーボネートは 3.1. で述 ぺたように，完全な無定形物であり，また $T_{g}$ 付近の温 度で熱処理してもX線回折写真からは無定形である。こ れらの試料を室温で延伸すると，Fig. 7 のような強伸 度曲線を得ることができる。図中に示すように, 初期降 伏応力を $G_{1}\left(\mathrm{~kg} / \mathrm{cm}^{2}\right)$, 破断応力を $G_{2}\left(\mathrm{~kg} / \mathrm{cm}^{2}\right)$ 扰よび 破断伸度 $L_{2}(\%)$ で以後表示する。

熱処理試料は末処理に比べて, $G_{1}$ が増加するが $G_{2}$, $L_{2}$ はむしろ減少する傾向があり，その曲線の一例を Fig. 7 の II に示した。

$G_{1}, G_{2}$ 特よび $L_{2}$ と処理温度との関係を Fig. 8〜10 に示した。試料にバラッキがあるため標準偏差を計算し 罒中に示した。また熱処理による影響を試料間のバラッ キと分離するために分散分析を行ない下表によって，水

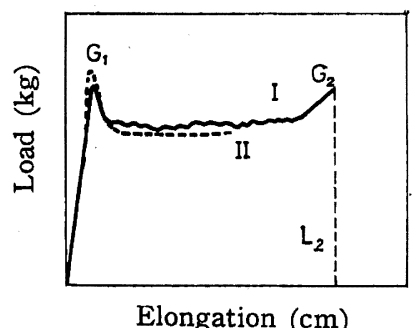

I: Untreated, II: Heat-treated

$G_{1}$ : Yield strength, $G_{2}$ : Ultimate strength

$L_{2}$ : Elongation at break

Fig. 7. Generalized tensile stress-strain curve for amorphous polycarbonate. 


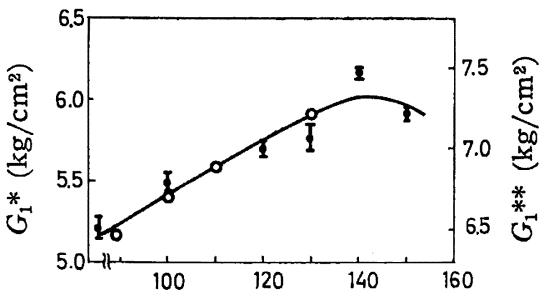

Temperature of treatment $\left({ }^{\circ} \mathrm{C}\right)$

$G_{1}{ }^{*}(\bullet)$ : This experiment $G_{2}{ }^{* *}(0)$ : From Golden et al ${ }^{13)}$

Time of treatment $16 \mathrm{hr}$

Fig. 8. Change in yeild strength, $G_{1}$ with temperature of treatment for polycarbonate.

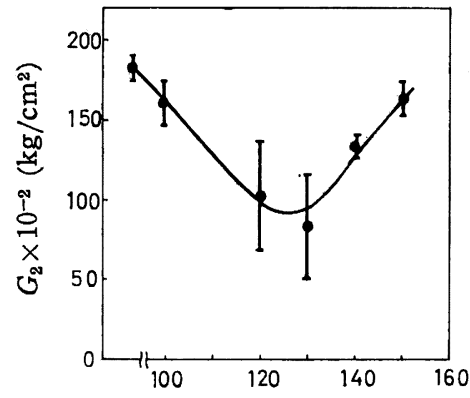

Temperature of treatment $\left({ }^{\circ} \mathrm{C}\right)$

Time of treatment $16 \mathrm{hr}$

Fig. 9. Change in ultimate strength, $G_{2}$ with temperature of treatment.

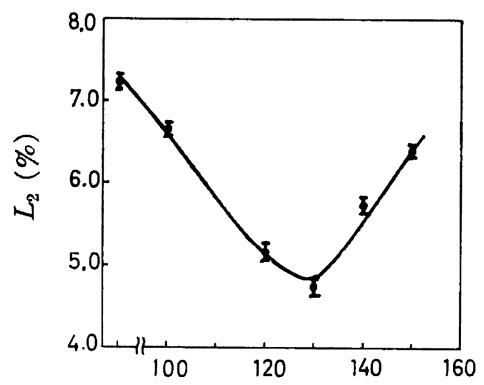

Temperature of treatment $\left({ }^{\circ} \mathrm{C}\right)$

Time of treatment $16 \mathrm{hr}$

Fig. 10. Change in elongation at break, $L_{2}$ with temperature of treatment.

準 5\%で検定を行なった。その結果は，熱処理による変 動が有意であったので，その効果は試料のバラッキより 大きいことが確かめられた。Fig. 8〜10 の処理洔間はい ずれも 16 時間である。初期降伏応力は $140^{\circ} \mathrm{C}$ 度までは,

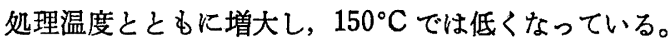
試料の作製方法，測定方法など異なる Golden ら ${ }^{13)}$ の結 果から換算したデータもFig. 8 飞記入したが，同じよ らな傾向を示すことがわかる。一般に $G_{1}$ は二次結合の 切断したところと解釈されている ${ }^{14)}$ 。Fig. 6 に示した ように $T_{g}$ のピークの高さが増すほど密度も增大してい るので，ガラス状態の充てんが密になり分子間結合が大 きいと考觉られる。したがって $G_{1}$ の増大とピーク高さ の增大とが対応しているのは，この上らな構造の反映で あると考学られる。

また $G_{2}, L_{2}$ はいずれも $130^{\circ} \mathrm{C}, T_{g}$ 付近で最小值を とっている。これは Fig. 7 でも示したよらに, 処理試 料ではネッキングしたまま破断し，すべりが起こらない ためで，熱処理によってブリットルな陚料に変化したこ とを示し，延伸性が減少することがわかった。Fig. 8〜10 で, $150^{\circ} \mathrm{C}$ 処理で $G_{1}$ は減少し, $G_{2}, L_{2}$ は増大してい る。この原因としては，一つはガラス転移領域での急冷 効果のため (2.1. で述べたよらな処理方法では) 未処理 試料の牲質に近づくこと，他の一つとしては先に述べた $\mathrm{X}$ 線的には検知されない微結晶の発生と，その束䋠によ るためと考えられる。

Fig. 11 に $130^{\circ} \mathrm{C} て ゙$ 処理して，処理時間を変えた場合 の， $G_{1}$ 打よび $L_{2}$ の結果を示した。先に述べた Golden ら ${ }^{13)}$ の結果をあわせて記入した。Fig. 5 と対応した関 係が得られる。

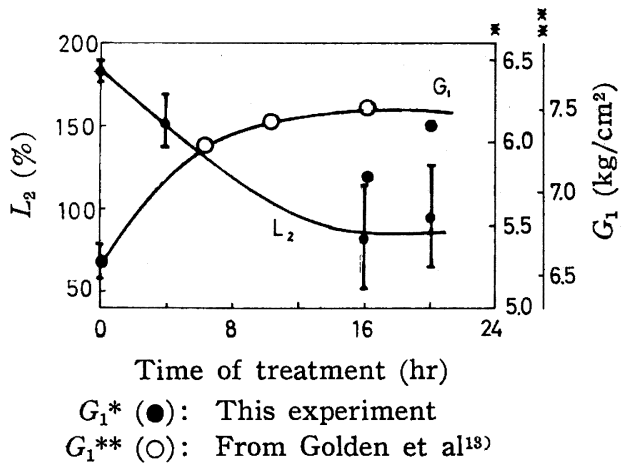

Temperature of treatment $160^{\circ} \mathrm{C}$

Fig. 11. Change in yield strength, $G_{1}$ and elongation at break, $L_{2}$ with time of treatment.

Ftg. 12 には $T_{g}$ におけるピークの高さと, $L_{2}, G_{1}$ の 関係を示した。バラッキがあるが処理温度, 処理時間が 違っていても， $L_{2}, G_{1}$ とともにピーク高さとの間にほぼ 比例関係があり， $T_{g}$ に和计るピーク高さが, Fig. 6 の 密度とも関連して,ガラス状態を知る一つの目安となり， これと延伸性との間にほぼ一義的関係があることを示し 
ている。

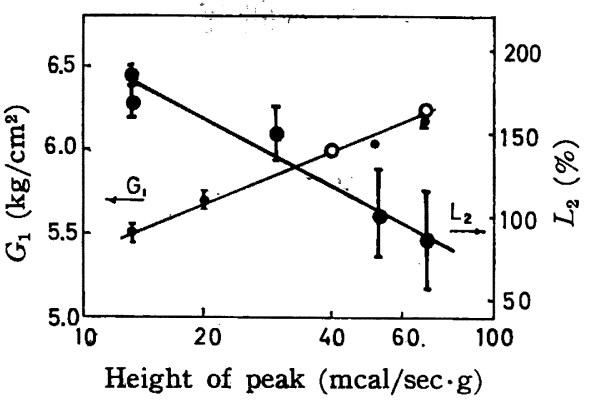

Fig. 12. Relationship between yield strength, $G_{1}$ and elongation at break, $L_{2}$ and height of transition peak for amorphous polycarbonate.

\section{文献}

1) B. Wunderlich, D. W. Bodily: J. Polymer Sci., 6, C, 137 (1967)
2) M. V. Volkeinstein, Y. A. Shaponov: Vysokomol. Soed., 3, 1738 (1961)

3）畠山立子，金綱久明：高化，26, 68 (1969)

4）畠山立子, 金綱久明：高化，26, 680 (1969)

5) 三石幸夫, 黒田洋次：緎学誌，24，11 (1968)

6) 三菱江戸川化学：ニーピロン技術資料集 (物性篇)

7) J. M. O'Relly, F. E. Karaz, H. E. Bair: $J$. Polymer Sci., C 6, 109 (1964)

8) 冨川昌美, 藤本徳樹： 高化, 25, 625 (1968)

9）藤本輝雄，井上幸彦：工化，63，1524 (1960)

10) F. P. Reding, J. A. Faucher, R. D. Whitman: J. Polymer Sci., 54, 556 (1961)

11）畠山立子，小川成夫：高化，25, 556 (1968)

12）畠山立子, 小川成夫：高化，25, 563 (1968)

13) J. H. Golden, B. L. Hammant, E. A. Hazell : J. Appl. Polymer Sci., 11, 1571 (1967)

14) R. Meredith: The Mechanical Propeties of Textile Fibres, 276 (1956) North-Holland Publ. Co.

\title{
On Drawability and Fine Structure of Amorphous Polycarbonate
}

\author{
by Tatsuko Hatakeyama* and Hisaaki Kanetsuna*
}

The effect of heat-treatment below glass transition temperature $\left(T_{g}\right)$ on drawability of amorphous polycarbonate has been studied.

In the DSC thermogram for amorphous polycarbonate, the glass transition peak was found at about $130^{\circ} \mathrm{C}$ and no other transitions were recognized. It was found from X-ray diffraction pattern, that amorphous structure did not change in heat-treatment below $T_{g}$. The height of the transition peak became higher with heat-treatment near $T_{g}$ and was proportional to the density of the samples. Therefore, the amorphous samples having different packing density of chain were obtained by heat-treatment.

Change is in yield srength $\left(G_{1}\right)$, ultimate strength $\left(G_{2}\right)$ and elongation at break $\left(L_{2}\right)$ were measured from stress-strain curve and they were compared to the height of transition peak. The yield strengh increased and ultimate strength and elongation at break decreased proportionally with increasing the height of transition peak.

These results suggest that enthalpy amorphous polycarbonate in glassy state decreases and the force of secondary bonds increases by the heat-treatment near $T_{g}$.

KEY WORDS Amorphous / Heat Treatment / Glass Transition / DSC / Density / Yield Strength/Elongation/

\footnotetext{
* Research Institute for Polymers and Textiles (4-Sawatari, Kanagawa-ku, Yokohama)
} 